\title{
ВІДОБРАЖЕННЯ КОМУНІКАТИВНИХ ТАБУ В УКРАЇНСЬКИХ ПАРЕМІЯХ
}

Єловська Ю. В. Відображення комунікативних табу в українських пареміях.

У статті розглядається проблема зв'язку комунікативних табу з народними віруваннями й повір'ями, наводяться приклади відображення мовних, тематичних і контактних табу в українських пареміях.

Ключові слова: комунікативні табу, мовні табу, паремії.

Еловская Ю. В. Отражение коммуникативных табу в украинских паремиях.

В статье рассматривается проблема взаимосвязи коммуникативных табу с народными верованиями и поверьями, приводятся примеры отражения словесных, тематических и контактных табу в украинских паремиях. 
Ключевые слова: коммуникативные табу, словесные, тематические, контактные табу, паремии.

Yelovska Yu. V. Communicative taboos in Ukrainian proverbs and sayings.

This article examines the interconnection between communicative taboos religion and beliefs, gives the examples of word, topic and contact taboos in Ukrainian proverbs and sayings.

Key words: communicative taboo, word, topic, contact taboo, proverbs, sayings.

Мова $є$ невід'ємною складовою культури кожного народу, їхній взаємозв'язок та взаємовпливи не викликають сумнівів. Як зазначив Е. Сепір, «Культуру можна визначити як те, що суспільство робить і думає. Мова $є$ те, як думають» [3, с. 321]. Мова відображає загальні компоненти загальнолюдської культури та своєрідність культури конкретно взятого народу.

Невід'ємною частиною культури окремої нації $\epsilon$, зокрема, так званий мовленнєвий етикет, який охоплює сукупність усталених форм спілкування, прийнятих відповідно до соціальних ролей комунікантів i моральних норм поведінки людей у суспільстві [1, с. 198]. Одна 3 його важливих складових - комунікативні табу, під якими розуміють мовні, тематичні та контактні заборони у спілкуванні [1, с. 265].

Мовні табу охоплюють заборони на вживання окремих слів та словосполучень. Тематичні табу - це заборони на обговорення певних тем в акті спілкування. Контактні табу забороняють будь-які форми міжособистісного спілкування [1, с. 340].

У сучасному світі, незважаючи на шалений розвиток науковотехнічного прогресу та нескінченну кількість нових відкриттів у різних галузях науки і техніки, феномен табу продовжує існувати [2]. Як зазначає більшість західних лінгвістів, табу є загальним, національним, сучасним та динамічним явищем.

Про різні типи табу, пов'язані з магічним уявленням, говорив ще Дж. Фрезер [4, с. 235, 239, 241]. Зокрема, відомий англійський етнолог згадує табу на власні імена, імена родичів та померлих, імена правителів, святих та богів. Учений зазначає, що для первісної людини не існує чіткого розмежування між словами та речами, вони нерозривно поєднані в реальному світі, а тому однаково вдало можна здійснювати магічний вплив на людину як через матеріальні речі, що їй належать, так і через слова та імена, тим самим надаючи їм особливого священного змісту [4, с. 174].

На думку П. Флоренського, який також надає слову сакрального змісту, очевидним $є$ той факт, що з давніх-давен слово вважалося не тільки набором звуків, знаком для називання предметів, станів та явищ, а й виступало акумулятором певної духовної енергії, полярність якої могла бути різною, відповідно до комунікативної мети адресанта [6, с. 12].

Не дивно, що в українській народній творчості збереглося безліч прислів 'їв, які відображають силу слова у прямому його сенсі: Шабля ранить тіло, а слово - душу; Слово може врятувати людину, слово може $і$ вбити; Гостре словечко коле сердечко; Добре слово будує, а зле руйнує; Слово не 
стріла, а ранить глибоко; Бджола жалить жалом, а чоловік - словом; Впік мене тим словом, не треба й вогню; Чиєсь одне слово губить діло (1, с. 17).

Численні комунікативні застороги відображають вірування українців у різноманітні потойбічні сили. Упевненість у магічній силі слова впливала і на формування евфемістичних замінників слів, які позначали лихо, хвороби, нечисті сили. Так, наприклад, замість лексеми нещзастя нерідко в українській народній творчості вживається слово вовк. Така семантична заміна грунтується на асоціативних зв'язках символу вовка 3 лихом, небезпекою, егоїзмом та ненажерливістю [3, с. 103]. Такі прислів'я, як Не визивай вовка з ліса; За вовка мовка, а вовк в хату суне (4, с. 147), опосередковано застерігають мовця від уживання подібних словосполучень, щоб відвернути нещастя та не накликати на себе лиху долю.

Комунікативні застороги стосуються також i прямого вживання слова лихо, оскільки вважається, що такими діями людина опосередковано притягує біду: Сказано лихо - не бути добру! Хто лихом жартує, той же його куштує; Коли тихо, не буде й лиха (3, с. 158).

У світорозумінні українців існує багато пересторог та обмежень щодо часу виконання певної діяльності, зокрема, й комунікативної. Так, існують заборони спілкування в певні проміжки часу, бо люди вірили, що бувають лихі години, коли не слід розмовляти: $B$ добрий час сказати, а в лихий промовчати; В добру годину було б сказано; Не під ніч згадуючи (3, с. 326). Деякі дні тижня, безпосередньо середа і п’ятниця, також накладають певні обмеження на виконання різних видів діяльності. Так, спів у п’ятницю вважався великим гріхом, оскільки праведні християни вірили, що цей день потрібно проводити у спокої, відкласти усі хатні справи, щоб не накликати на себе лихо. Не дарма існують такі народні прислів'я: Співання в п'ятницю, а снідання в неділю ніколи не минеться; Як воно трапиться: коли середа, а коли й n'ятниця (3, с. 353), які нагадують особливий статус цих неробочих днів [3, с. 492, 534].

Лайлива лексика та прокльони також виступають комунікативним табу в мовленнєвому етикеті українців. Під лайливим словниковим складом тут маємо на увазі не тільки брутальні слова, а й особливі вислови, які своїм походженням пов'язані зі специфікою світосприйняття та релігійними віруваннями українців. Лайка розглядається не тільки як неприпустиме явище в процесі спілкування, а й гріхом: Лайка лається, бо з дідьком знається; Говорити можна, а лаятись не треба (3, с. 62); Батькуєи, а гріх; Мудра голова не говорить лихі слова (2, с. 126).

Табуюються й прокльони, які за народними віруваннями можуть безпосередньо впливати на адресанта. Особливо поширені повір'я щодо заборон на материнські прокльони, бо вони вважаються найбільш упливовими: Батькова та матчина молитва з моря виймає, а проклін в калюжі топить [2, с. 486]. 
Прокльони та брутальні вислови також мають певні обмеження щодо вживання окремих слів. Замість називання безпосередньо представників демонічного світу чорт, у лайливій лексиці вживаються слова-замінники Гаспидський сину; Яропудів сину! ;Іродів син! ; Кайнова ти дочка! ; Побила б їх морока! (3, с. 329, 331, 334, 338 ) тощо.

Віра в магічну силу слів та їх асоціативний зв'язок із предметами або явищами, які вони називають, зумовила появу евфемістичного забарвлення окремих виразів задля убезпечення особи мовця від їхнього негативного впливу. Так, у прислів'ях, що мають на увазі побажання скорої смерті або нещастя, замість лексем, які заздалегідь мають негативне семантичне навантаження (чорт, смерть, лихо тощо), використовуються семантично позитивні компоненти. Паремії Дзвонять по душі; I святитель не поможе, як заспівають «Святий Боже» (3, с. 343) змальовують сповіщення про смерть людини, хоча саме слово смерть навмисне не вживається. Подібна евфемістична заміна спостерігається в лайливих виразах $A$ убий тебе Божа сила!; Щоб ти не діждав ні Петра, ні Павла, ні дрібних святих!; Хай його гнів Божий поб'є!; Щоб його земля свята не приймала; Щоб ти не діждав завтрашнього дня; Щоб тобі дубовий хрест! (2, с. 327, 329).

Сакральний характер в українській культурі має вибір імені, яке зберігається в таємниці до моменту хрещення самої дитини, щоб захистити іiі від темних сил. Ім'я людини $є$ священним і потребує захисту. Назвати його означає розкрити таємницю. Ще Дж. Фрезер наводив докази особливого статусу імені у віруваннях первісних племен, указував, що імена жерців, правителів, а подекуди й пересічних представників племені зберігалися у великій таємниці, оскільки, знаючи ім'я людини, чаклун або злі духи могли вчинити шкоду його носієві [8, с. 239].

Як приклад тематичних табу можна навести заборону згадувати в поганому сенсі покійників: Про покійників або добре або нічого (3, с. 160). У спілкуванні з вагітною жінкою уникають обговорення тем, пов'язаних із хворобами, тяжкими тілесними ушкодженнями та будь-якими іншими лихими явищами, щоб не наврочити майбутній породіллі нещасливої долі.

Контактні табу, за визначенням Ф. Бацевича, стосуються заборон на будь-які форми міжособистісного спілкування. Однією 3 перших засторог $\epsilon$ уникнення зустрічей із потойбічними демонічними істотами (чорт, упир, русалка) та людьми (чарівники, відьми), які наділені надприродними силами, оскільки подібні ситуації можуть мати негативні наслідки: 3 чортом не вітайся, а ще краще - не стрічайся; Як поспориш 3 відьмою, то мерщій іди до їхнього начальника - опиряки - $і$ проси його, щоб він тебе помилував $і$ наказав тій відьмі, щоб вона не займала тебе [5, с. 217]. Обрядові русальні пісні не мають комунікативних засторог, але в розповідному стилі переповідають історію зустрічі дівчини і русалки, та іiї наслідки: 
Ой біжить, біжить мала дівчина,

А за єю да русалочка:

- Ти послухай мене, красна панночко,

Загадаю тобі три загадочки,

Як угадаєш - до батька пушу,

Не угадаєи - до себе возьму:

- А щзо росте без кореня,

А щуо біжить без повода,

А щио иввіте да без ивіту?

- Камінь росте без кореня,

Вода біжить без повода,

Папороть ивіте без иявіту.

Панночка загадочок не вгадала -

Русалочка панночку залоскотала [5, с. 167].

Отже, бачимо, що поява низки комунікативних табу в мовленні українців грунтується на народних віруваннях і повір'ях, що яскраво відображено в пареміях. Основу розглянутих прикладів комунікативних табу становить віра в магічну силу слова, у його органічний зв'язок із річчю, яку воно називає. Заборони стосуються передусім тих слів, висловів, тем спілкування, самих комунікативних актів, які мають негативний зміст (смерть, лихо, хвороби, нечиста сила тощо).

\section{Література}

1. Бацевич В. Ф. Основи комунікативної лінгвістики : [підручник] / В. Ф. Бацевич - К. : Академія, 2004. $-344 \mathrm{c}$.

2. Знаки української етнокультури : [словник-довідник] / авт.-уклад. Жайворонок В. В. - К. : Довіра, 2006. $-706 \mathrm{c}$.

3. Кочерган М. П. Вступ до мовознавства : [підруч. для студ. філол. спец. вищ. навч. закл.] / М. П. Кочерган - К. : Академія, 2001. - 368 с.

4. Фрэзер Д. Д. Золотая ветвь: Исследование магии и религии / Джеймс Джордж Фрэзер; [пер. с англ.]. - [2-е изд.]. - М. : Политиздат, 1986. - 703 с.

5. 100 найвідоміших образів української міфології / [Завадська В., Музиченко Я., Таланчук О., Шалак О.]. - К. : Орфей, 2002. - 448 с.

6. Зайцева С. Л. Онтологічний зміст концепту «Енергійність мови» : автореф. дис. на здобуття наук. ступеня канд. філос. наук: спец. : 09.00.01 «Онтологія, гносеологія, феноменологія» / С. Л.Зайцева. Київ, 2005. - 19, [12] с.

7. Евсеева Н. А. Культура и языковые запреты / Н. А. Евсеева // Вестник Московского государственного университета : Серия 19 : Лингвистика и межкультурная коммуникация. - 2000. - № 2. - С. $43-47$.

8. Скрипник Г. Народні вірування, демонологія, космологія / Г. Скрипник, О. Курочкін. [Електронний ресурс]. - Режим доступу до статті: http://spogad.at.ua/publ/0-3

\section{Список використаних джерел}

1. Олійник О. Б. Світ українського слова / О. Б. Олійник [Інститут Українознавства Київського університету ім. Тараса Шевченка]. - . К. : Хрещатик, 1994. - 416 с.

2. Стахів М. Український комунікативний етикет: [навч. посібник] / М. Стахів. - К. : Знання, 2008. - 245 с.

3. Прислів’я та приказки : Взаємини між людьми / [упоряд. М. М. Пазяк]. - К.: Наук. думка , 1991. - 440 с.

4. Українські народні прислів'я та приказки людьми / [упоряд. В. Бобкова, Й. Багмут, А. Багмут]. К. : Держ. вид. худ. літ-ри, 1963. - 790 с. 